\section{PINTURAS DE PAISAGENS E O REGISTRO DOS IMPACTOS DAS FONTES DE ENERGIA NAS PAISAGENS GEOGRÁFICAS}

Jacqueline Myanaki

Rosângela Dalla Corte²

\section{INTRODUÇÃO}

Tendo como referência a interface entre Geografia e Arte, buscouse construir um perfil das transformações da paisagem geográfica no mundo contemporâneo identificando impactos advindos da ampliação da exploração das fontes de energia e a utilização da energia elétrica a partir da análise do registro dessas transformações nas pinturas de paisagens realizadas principalmente por artistas brasileiros.

A matriz deste artigo é um Projeto FIPE 3 Júnior voltado à pesquisa das fontes de energia e o respectivo impacto nas transformações da paisagem cultural, com o objetivo final de produção de um arquivo

1 Colégio Técnico Industrial de Santa Maria. Doutora em Geografia pelo DG/USP, Licenciada em Artes pela UNESP e professora de Geografia do CTISM - UFSM. jacqueee@ ig.com.br.

$\triangle$ Av. Roraima, 1000, prédio 5, Camobi, Santa Maria, RS. 97105-900.

2 Professora do Departamento de Geociências da Universidade Federal de Santa Maria (UFSM).rosidallacorte@hotmail.com.

RFaixa de Camobi, prédio 13, Camobi, Santa Maria, RS. 97105-900.

3 Projeto desenvolvido no período de 2011 a 2014 com recursos do Programa de Bolsas de Iniciação Científica ou Auxílio à Pesquisa do Fundo de Incentivo à Pesquisa (FIPE) para servidores recém doutores da Universidade Federal de Santa Maria. O objetivo do projeto está centrado na construção de um perfil das transformações da paisagem cultural contemporânea advindas direta ou indiretamente da ampliação do uso das diferentes fontes de energia e respectivas redes de distribuição a partir da análise de pinturas de paisagens, com vistas à elaboração de um catálogo virtual com textos e imagens a ser utilizado como material didático para o ensino médio. $O$ projeto conta com auxílio de um bolsista para a realização da pesquisa de imagens e montagem do material didático. virtual de pinturas de paisagens relacionadas ao tema e respectivas análises, para ser utilizado como material didático no Ensino Médio.

Por tratar-se de um projeto voltado para a produção de material didático para o Ensino Médio, com vistas ao estudo da temática das fontes de energia a partir da visão interdisciplinar da Geografia e da Arte; e por tratar-se de um projeto no qual se propõe que a Arte também seja objeto de estudo e não mero instrumento didático, o material pesquisado restringiu-se à obra de artistas brasileiros ou de artistas que retrataram a paisagem brasileira.

Sendo assim, parte das reflexões e do material selecionado para o projeto citado acima está presente neste artigo, no qual, as obras de arte pesquisadas são tomadas como referenciais para a compreensão das relações entre tempo e espaço que as atividades antrópicas imprimem nas paisagens geográficas, considerando-se que a dimensão Cultural da Geografia vem ampliando as possibilidades de investigação da produção do espaço geográfico por meio da interdisciplinaridade e permitindo que, neste caso, a função social da arte não fique restrita às galerias, museus ou acervos particulares.

Para este artigo, as imagens selecionadas restringiram-se aos impactos e às transformações da paisagem advindas principalmente do uso da energia elétrica. A temática das fontes de energia tem ganhado cada vez mais destaques nas discussões dos diferentes meios e no cenário mundial, em razão dos impactos de diversas naturezas que causam ao ambiente, estimulando o debate na busca de soluções e alternativas ao modelo energético tradicional.

A seleção dos quadros de paisagens segue roteiro análogo à lógica da transformação das paisagens geográficas, identificando três grupos de paisagens: paisagens pré-impactadas, cuja instalação de processos de produção de energia elétrica ainda não haviam modificado essas paisagens; paisagens impactadas, cujo arranjo material revela novas 
estruturas relativas ao uso da energia elétrica e fontes de energia e, por fim, paisagens que revelam potencial energético, considerando a possibilidade de uso das fontes de energias renováveis ou não.

\section{Geografia CULTURAL, PAISAGEM E ARTE}

A Geografia tem como essência estudar as relações entre a sociedade e a natureza. Para analisar essas relações em sua totalidade, é comum a utilização de algumas categorias analíticas, como espaço, lugar, paisagem, território e região. Dentre estas categorias ou conceitos operacionais, a paisagem pode ser considerada um conjunto de formas naturais e culturais que constituem uma só totalidade e cujas nossas percepções podem abarcar.

A noção de paisagem tem acompanhado as transformações pelas quais a ciência Geográfica têm passado desde o século XIX, quando adquiriu status de ciência autônoma. A relação entre paisagem e o objeto de estudo da Geografia, alternou influências do determinismo ambiental e o seu entendimento como sistema passando por um período de "esquecimento" e ressurgindo com a emergência das inquietações ambientalistas, até voltar a adquirir destaque nas pesquisas da Geografia Humanista, da década de 1950, e mais fortemente com a renovação da Geografia Cultural, a partir da década de 1970, como enfatizado na referência a seguir:

Novas perspectivas apareceram no domínio dos estudos sobre a paisagem no final dos anos setenta. A paisagem cessou de ser concebida como um dado objetivo. O enfoque foi, a partir de então, colocado na dialética entre a dimensão objetiva e a dimensão subjetiva do olhar e sobre a relação entre a paisagem como marca da cultura e a paisagem como matriz da cultura. (CLAVAL, 2002, p. 160).
Dentro desta perspectiva da Geografia Cultural, a paisagem tem sido objeto de estudo com enfoques diversos. Destaques para a importância da paisagem urbana, a paisagem como texto, como imagem cultural, as paisagens imaginárias, paisagem como conivência, paisagem como marca e matriz, paisagens vernaculares e paisagens sonoras. Com maior ou menor subjetividade, dependendo do método de abordagem, a noção de paisagem tem ganhado destaque nos estudos de Geografia Cultural, com muitas pesquisas envolvendo arte e paisagem, principalmente obras de arte figurativas que permitem ampliar a compreensão geográfica sobre determinadas regiões.

Pintores como Constable, Turner, Cézanne, Van Gogh e Paul Gauguin têm tido suas obras submetidas a análises mais minuciosas do ponto de vista geográfico. O mesmo se deu com o pintor brasileiro paulista Miguel Dutra (1810-1875), que retratou em suas telas os varvitos e as paisagens de Itu e região, no interior de São Paulo. O ensaio sobre a obra deste artista, realizado por Monteiro (2008), permite compreender o quanto a noção de paisagem é uma determinação sociocultural (ROGER, 1997, p. 130) e portanto reveladora das construções históricas e espaciais.

Considerando-se as oscilações no interesse sobre a noção de paisagem na Geografia e a recente retomada do conceito por parte da chamada Geografia Cultural, paralelamente pode-se considerar também uma trajetória da paisagem, como gênero da pintura, que revela uma transfiguração das representações dentro deste gênero, da paisagem figurativa à paisagem abstrata (MYANAKI, 2008).

As pinturas de paisagens anteriores à afirmação do gênero por volta do século XVIII, são paisagens simbólicas, chamadas por Berque (1995) e Roger (1997) de proto-paisagens, cuja natureza figura nas telas, mediada por símbolos. O desenvolvimento do gênero paisagístico na arte ocidental, resultou nas representações figurativas cujo princípio 
básico foi a incorporação das técnicas da perspectiva renascentista, se tornando um esquema, um modelo básico do contato com a natureza (CAUOUELIN, 2007).

Contudo, uma ruptura com estes referenciais da perspectiva e das formas de composição, ocorre na virada do século XIX para o século XX. A linha do horizonte passou a ser delineada por edificações, a natureza perdeu importância para os artefatos humanos, a expressão da subjetividade ganhou espaço nas telas, múltiplos pontos de vista dão lugar ao ponto de fuga único e experimentos com mistura de tintas coloridas, técnicas mistas e efeitos de luz e sombra resultaram em novas correntes artísticas.

Dentre as novas correntes artísticas mencionadas pode-se citar o Impressionismo, Expressionismo, Cubismo ou Raionismo, dentre outras, nas quais a paisagem, apesar do caráter mais abstrato das representações e da dissolução da figura, adquiriu uma expressão renovada com a valorização dos efeitos de luz, do movimento, da subjetividade, a superposição de planos ou a valorização das cores, conforme o movimento artístico.

No Brasil, o Modernismo da década de 1920, que desdobrou-se em manifestações artísticas distintas (literatura, teatro, cinema, pintura, escultura, etc.), teve nas artes plásticas representantes que, apesar de carregarem influência das vanguardas européias, desenvolveram linguagem plástica própria e com temática nacional, cujas pinturas de paisagens, quando analisadas, revelam referenciais significativos das transformações dos arranjos da paisagem geográfica.

Observa-se assim que há um paralelismo entre as transformações na Arte, na Geografia e na própria paisagem geográfica, permitindo supor que uma análise conjunta é possível e complementar, permitindo abarcar a paisagem em suas múltiplas dimensões, como afirma Corrêa.
A paisagem geográfica apresenta simultaneamente várias dimensões que cada matriz epistemológica privilegia. Ela tem uma dimensão morfológica, ou seja, é um conjunto de formas criadas pela natureza e pela ação humana, e uma dimensão funcional, isto é, apresenta relações entre as suas diversas partes. Produto da ação humana ao longo do tempo, a paisagem apresenta uma dimensão histórica. (CORRÊA; ROSENDAHL, 2004, p. 8)

Assim, considerando a multiplicidade de formas de representação e a multiplicidade de dimensões nas quais a paisagem geográfica se apresenta, a proposta aqui foi compor um estudo que abrangesse a análise da paisagem geográfica e suas transformações, condicionadas pela ampliação da exploração de fontes de energia e uso da energia elétrica tendo como referencial pinturas de paisagens delineadas a partir de distintos olhares e técnicas.

Seguindo esta proposta apresentam-se pinturas de paisagens construídas dentro do modelo da perspectiva renascentista, como equivalente da natureza que figura ordenadamente construída dentro dos padrões da perspectiva e do ponto de fuga (CAUQUELIN, 2007), como por exemplo, a paisagem da Figura 1, de Frans Post. Mas também apresentam-se pinturas de paisagens que refletem o crescente processo de urbanização que as paisagens geográficas expressam: são as pinturas que revelam a natureza cedendo cada vez mais espaço para a natureza construída pelo homem por meio de técnicas que mesclam pontos de vistas, conjuntos de cores que expressam a subjetividade do olhar, valorizam as nuances da incidência de luz e sombra e revelam a dimensão cultural dos arranjos paisagísticos em escalas variadas e não mais presas à moldura e o enquadramento da perspectiva.

Com base nesta interface entre Arte e Geografia e na compreensão de que a Arte e suas formas de expressão não se constituem de objetos estáticos, mas sim de instrumentos de leitura do mundo e de cada um 
(BARBOSA, 2005) é que se estabeleceu a abordagem aqui apresentada a fim de construir um perfil das transformações que estão impressas nessas paisagens pintadas e nas paisagens geográficas permitindo melhor compreendê-las.

\section{FONTES DE ENERGIA, ENERGIA ELÉTRICA E IMPACTOS NA PAISAGEM}

Astransformações que o mundo contemporâneo vem apresentando, condicionadas pela difusão das tecnologias informacionais, tem resultado na intensificação e aceleração de fluxos de toda ordem, o que por sua vez têm ampliado as demandas por energia.

Considerando estas demandas em relação ao ritmo do crescimento mundial da população, as reflexões em torno da sustentabilidade que supõe a preocupação com as futuras gerações, têm resultado em aumento das pesquisas em torno das chamadas fontes de energias renováveis e formas de obtenção destas, como as pequenas centrais hidrelétricas, a biomassa, energia eólica, solar, geotérmica, etc. Estas formas de energia emergem como alternativa ao modelo energético tradicional, pois se tratam de energias ditas limpas, que causam menores impactos ambientais e não emitem gases do efeito estufa.

Entretanto, sabe-se que há impactos. Parte destes impactos são visíveis e facilmente perceptíveis na paisagem, outros impactos podem ser inferidos em regiões distantes da área produtora de energia, uma vez que a energia gerada nas hidrelétricas, por exemplo, é distribuída para lugares distantes. Independente da fonte primária de produção de energia elétrica, o fato é que a ampliação do seu uso no cotidiano, tanto urbano quanto rural, tem condicionado novos arranjos espaciais das paisagens ao longo de toda a área de transmissão e também nos pontos em que a energia é consumida.

Geograficidade | v.4, n.1, Verão 2014 ISSN 2238-0205
Na pesquisa realizada foram identificadas pinturas paisagísticas que podem ser classificadas em três grupos: as paisagens pré-impactadas, paisagens impactadas e paisagens que revelam potencial energético.

\section{PAISAGENS PRÉ-IMPACTADAS}

Neste grupo encontram-se paisagens cuja representação é anterior à instalação de projetos de exploração de fontes de energia e de produção de energia elétrica. São paisagens quase sempre pintadas dentro do modelo que deu origem ao gênero paisagem na pintura: "representação pictórica de um sítio ao ar livre, no qual a natureza desempenha o papel exclusivo ou preponderante." ${ }_{4}$

Nos exemplos aqui demonstrados o domínio é relativo ao uso dos recursos hídricos como fonte de energia. Atualmente, no Brasil, a maior parcela da energia elétrica produzida provém das hidrelétricas. Daí a importância das quedas d'água para a geração de energia elétrica. Os rios são represados e a força da queda d'água movimenta turbinas que geram eletricidade. Depois de movimentar as turbinas, as águas voltam para o rio sem sofrer nenhum tipo de alteração, por isso é considerada uma fonte de energia limpa e renovável, pois supostamente, não provoca a emissão de gases causadores do efeito estufa.

Presentemente, o Rio São Francisco e o Rio Paraná são importantes referências na produção de energia hidrelétrica no Brasil. Nestes rios, por exemplo, pode-se apreciar fragmentos paisagísticos pontuados pela presença de extensos lagos ou reservatórios a partir da inundação de áreas que submergiram a flora e expulsaram parcela significativa da fauna.

4 Definição de paisagem incluída no painel da exposição do acervo da Pinacoteca do Estado de São Paulo, comumente utilizada quando o gênero paisagem (da pintura) estava no seu auge, principalmente no século XVIII. 
Dentre os impactos relativos à construção de hidrelétricas é sabido que condenam comunidades inteiras à desestruturação física e alteram o modo de vida das populações locais; alteram o regime e o curso dos rios após o represamento; condicionam mudanças no microclima com o aumento da formação de nebulosidade e evaporação; alteram o processo de produção, transporte e deposição de sedimentos no entorno que pode causar problemas à própria barragem, bem como há relatos de emissão de gás metano por conta da decomposição da matéria orgânica que ficou submersa.

A paisagem da figura 1 é um dos vários documentos iconográficos realizados por Frans Post durante sua estadia de oito anos no Brasil (1637-45), trazido por Maurício de Nassau. Nesta tela vê-se um trecho do baixo São Francisco muito antes da instalação das 7 principais barragens no rio e outras dezenas de pequenas barragens na Bacia do Rio São Francisco, que resultou em milhares de famílias desalojadas, alteração dos ciclos de cheias e vazantes do rio, perturbação nos ciclos migratórios e reprodutivos de espécies de peixes e interferência nas atividades econômicas voltadas à pesca e à agricultura.

A paisagem que se vê no quadro é a de um rio que ainda tem suas margens tomadas pela fauna e vegetação típicas, principalmente à esquerda, ressaltando o estado quase inalterado da mata ciliar e a presença mínima de artefatos humanos. Os pequenos barcos representados à margem esquerda do Rio (à direita no quadro) junto ao morro onde estão atualmente as ruínas do antigo Forte têm pouco destaque na perspectiva em que a paisagem foi representada. Atualmente o município de Penedo-AL tem mais de 60 mil habitantes, mas nessa imagem ainda não há indícios do avanço da urbanização que tomaria conta das margens do Rio em boa parte de sua extensão.

O Rio São Francisco, neste quadro, ainda cumpre predominantemente, a função de meio fluvial de transporte e fonte

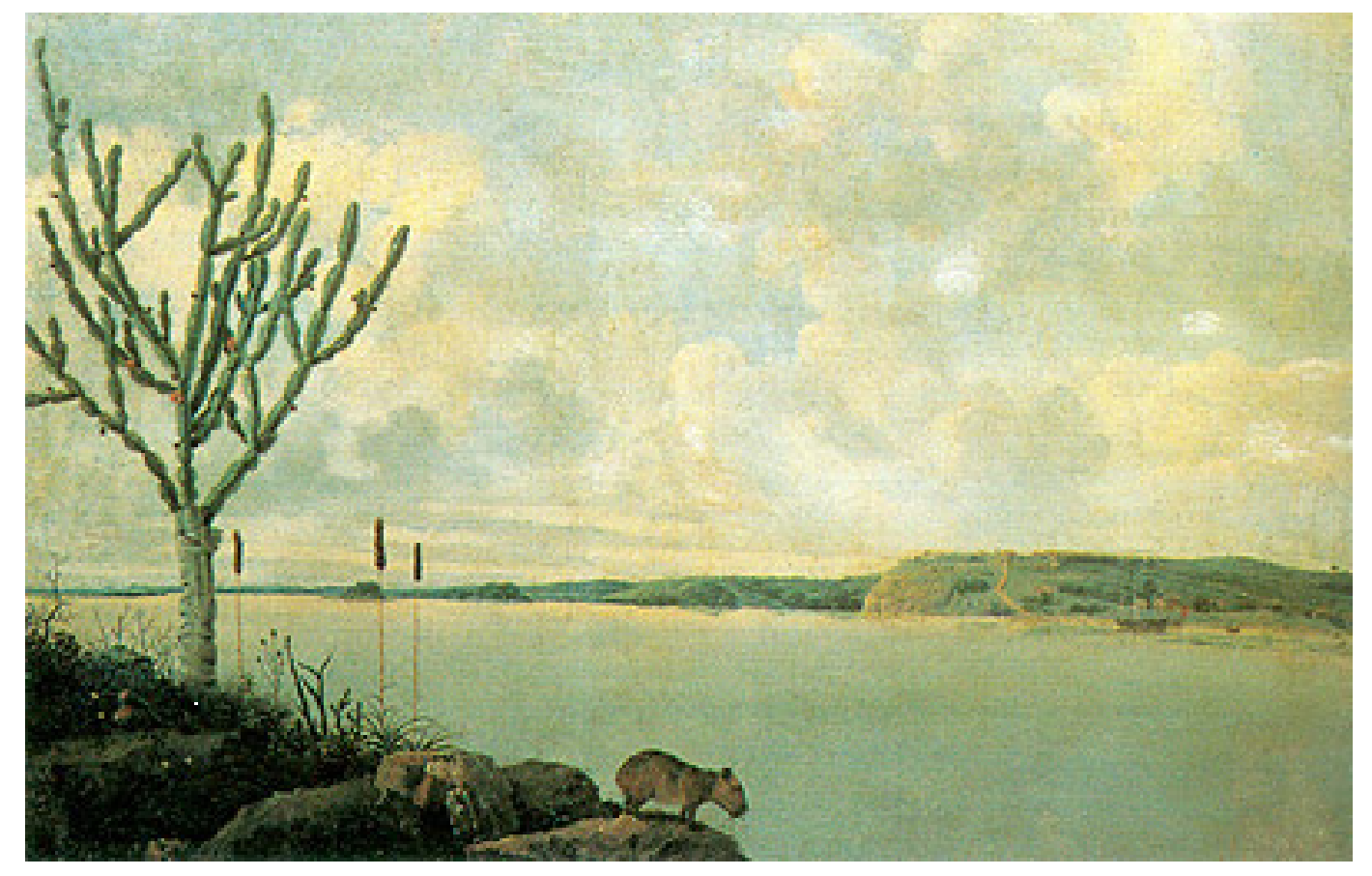

Figura 1 - POST, Frans. Rio São Francisco e o Forte Maurits, 1638. Óleo sobre tela, c.i.e., $60 \times 88 \mathrm{~cm}$. Museu do Louvre (Paris, França). Reprodução fotográfica autoria desconhecida.

Disponível em: <http://www.itaucultural.org.br>. Acesso em: 06 jun. 2011.

de alimento para o homem e animais de pequeno porte, como os que estão representados no primeiro plano, no centro da tela, abaixo. Provavelmente por esta razão o pintor entendeu, naquele momento, tratar-se de uma paisagem digna do gênero, uma vez que havia o predomínio da vegetação pouco modificada, da fauna típica, das águas limpas e da linha do horizonte desprovida de edificações.

Na figura 2, o pintor paranaense Lange Morretes realizou também um registro histórico das Cataratas do Iguaçu anterior ao represamento do Rio Paraná e da construção da Usina Hidrelétrica de Itaipu.

A análise desta paisagem, cujo correspondente no Estado do Paraná ainda permanece como um ícone do turismo, permite reflexões vinculadas à construção de Itaipu e o desaparecimento do Salto de Sete Quedas, um atrativo turístico equivalente às Cataratas e que 


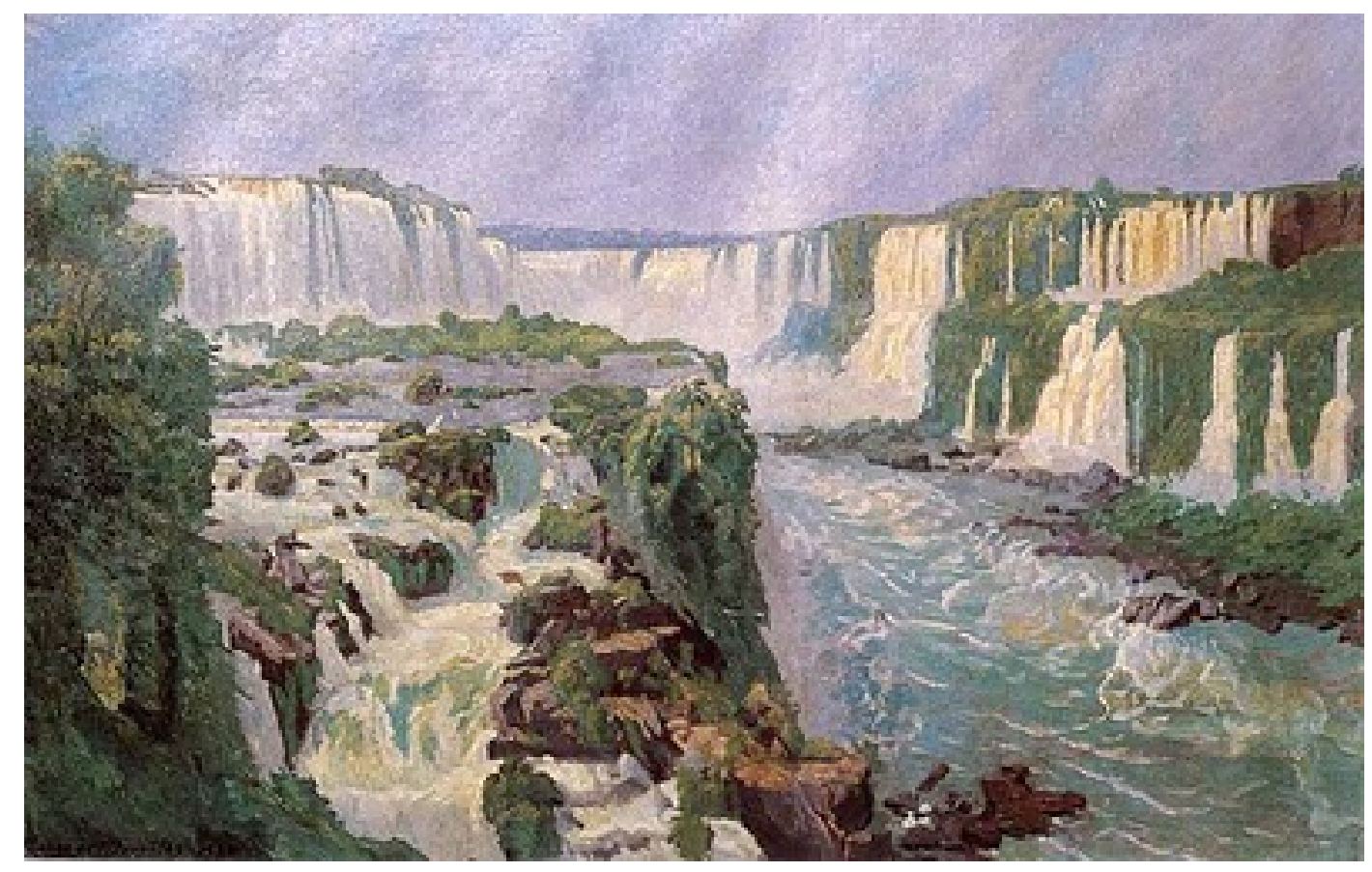

Figura 2 - MORRETES, Lange. Catarata do Iguaçu, 1920.

Disponível em: <http://vitoria-sucesso.blogspot.com/2010/07/pinturas-paranaenses.

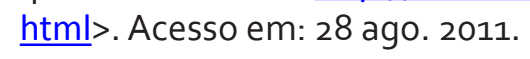

ficou registrado entre os impactos advindos da instalação da usina juntamente com a inundação de uma área de $1350 \mathrm{~km}^{2}$, aumento da umidade ambiental na região juntamente com as transformações na dinâmica do lençol freático, oferta deágua para agricultura, aumento de pragas e de doenças (fúngicas e bacterianas na agricultura) associadas ao aumento de nevoeiros, dentre os impactos dos ecossistemas naturais da região (Fundação IPARDES).

Ainda que a paisagem das Cataratas não exiba registro da presença humana, os impactos relativos à instalação da maior Usina Hidrelétrica do Brasil, devem considerar os impactos sociais, uma vez que para produzir 92,24MWh de energia "limpa e renovável" foram necessárias mais de 8500 desapropriações (REVISTA NOVO AMBIENTE) com resultados e reflexos de toda ordem: proprietários sem documentação que tiveram que provar na justiça a posse das terras para receber a indenização depositada em juízo, pressão imobiliária sobre as terras da fronteira com o Paraguai que eram mais baratas que as brasileiras, êxodo para as regiões vizinhas, mudança na dinâmica regional com o aumento da população flutuante que atuou na obra durante anos, dentre as interferências mais ressalientes.

Atualmente as Cataratas do Iguaçu e a Usina de Itaipu constituem uma "dobradinha" na oferta turística da região. Distantes apenas cerca de $38 \mathrm{~km}$, os pacotes ofertados pelas operadoras destacam a grandiosidade dos dois atrativos: a beleza natural das gigantescas quedas d'água em mais de 270 saltos indicada no pacote turístico ao lado da engenhosidade e da perícia arquitetônica da barragem de $196 \mathrm{~m}$ de altura e $7919 \mathrm{~m}$ de comprimento (Site Itaipu), comparada a uma catedral em razão do formato côncavo e com a clara intenção de sublimar o atrativo artificial sagrando-o no mesmo patamar do atrativo natural.

As figuras 1 e 2 além de registros históricos da paisagem geográfica, também podem ser analisadas como registros históricos de um processo de transformação da paisagem como gênero da pintura, que seguiu transformando-se tanto quanto a paisagem geográfica. Como foi citado anteriormente as pinturas de paisagens surgiram como um gênero voltado ao registro da natureza, ao ar livre, enquadrada dentro das regras da perspectiva, como afirma Cauquelin (2007).

O que se seguiu a este modelo na arte foram as pinturas de paisagens que já não estavam mais restritas aos elementos da natureza, mas que ampliaram o enquadramento aos artefatos humanos, permitiram novas regras na perspectiva, adicionando novos pontos de fuga ou admitindo a inclusão de pontos de vista simultâneos e com maior grau de subjetividade.

Tanto quanto a paisagem geográfica, de forma geral, foi ampliando sua porcentagem urbana sobre a rural, as áreas naturais pouco 
modificadas foram sendo substituídas pela ação antrópica, as representações na pintura também ganharam novas linhas, pontos, cores, e formas tal qual pode-se apreciar nas paisagens que apresentam impacto relativo ao uso e produção de energia elétrica.

\section{PAISAGENS COM IMPACTO RELATIVO AO USO E PRODUÇÃO DE ENERGIA ELÉTRICA}

No século XX um novo conceito de paisagem na Arte e na Geografia foi dominando o espaço nas galerias de arte e no mundo. A natureza passou a figurar como pano de fundo da nova dinâmica urbana, cujos postes de iluminação ganharam status de referencial na perspectiva ou mesmo protagonistas na temática representada: um evidente resultado da ampliação do uso da energia elétrica no mundo contemporâneo. Na Arte, a busca por um novo modelo de representação e o anseio por uma estética renovadora se harmonizou com os novos arranjos espaciais.

As pinturas deste grupo são registros de paisagens que, sabe-se, já foram impactadas pela instalação de usinas elétricas ou pela adoção de novas atividades econômicas voltadas à produção de energia.

A tela "Estrada de Ferro Central do Brasil" de Tarsila do Amaral (Figura 3) é um incontestável registro do Movimento Modernista no Brasil que atingiu várias formas de expressão artística, além da pintura. O movimento emergiu na São Paulo industrial, tendo como referência a Semana de Arte Moderna de 1922 e Tarsila, apesar de não ter participado do evento, é um dos mais importantes ícones da renovação da pintura daquele período.

As cores fortes e saturadas ou cores caipiras (uma alusão à sua origem interiorana paulista) como costuma-se atribuir à obra da artista, a rigidez das linhas e as formas contrastantes, refletem a paisagem industrial emergente naquele momento. $O$ crescimento da atividade industrial no Brasil nas décadas de 20 e 30, conferiram novas funções às cidades. O êxodo rural; o aumento da densidade demográfica nos centros urbanos e conseqüente pressão pelos serviços básicos; a instalação das fábricas pontuando a paisagem com suas chaminés, poluindo o ar, despejando

Geograficidade | v.4, n.1, Verão 2014 ISSN 2238-0205

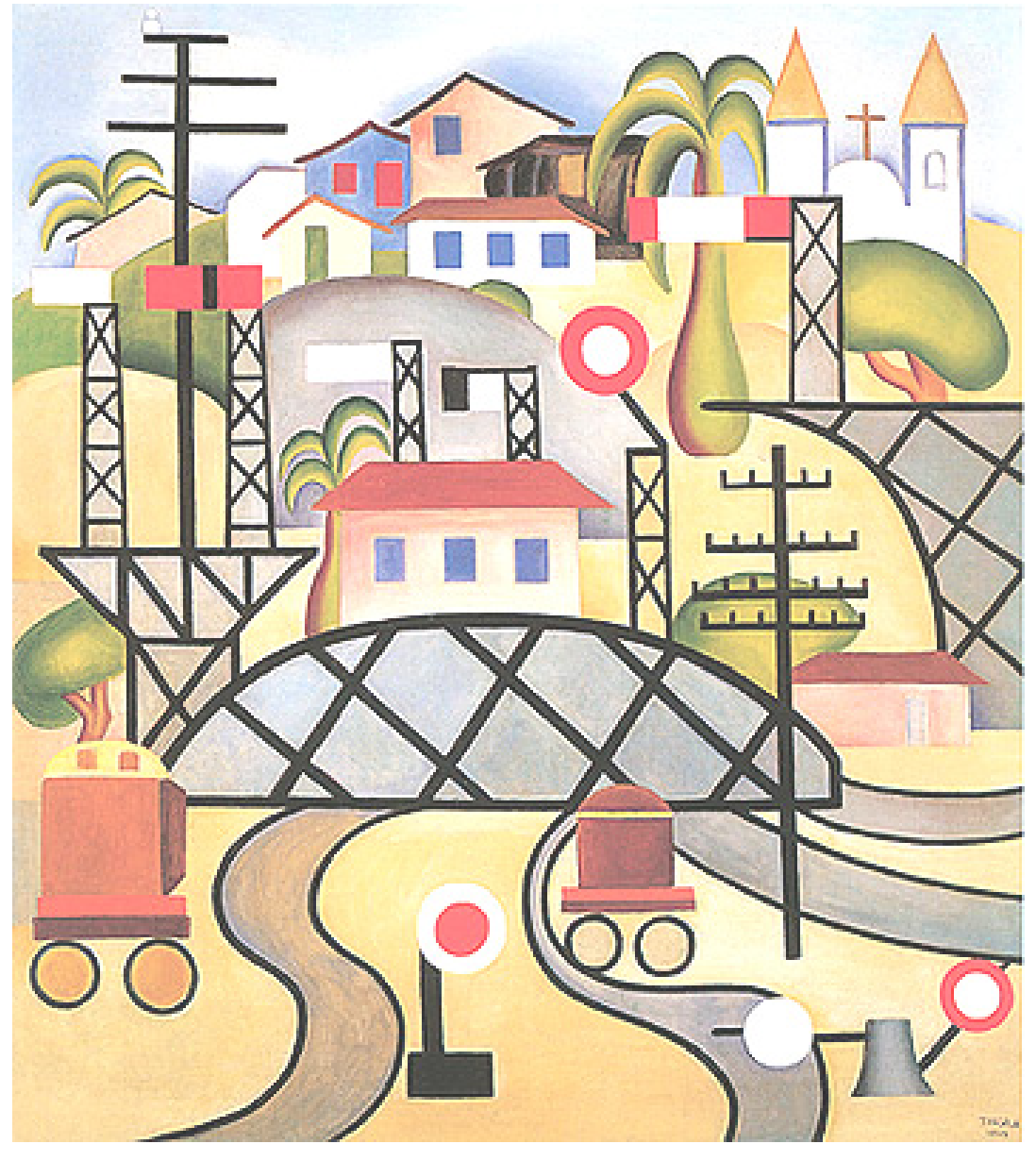

Figura 3 - AMARAL, Tarsila do. Estrada de Ferro Central do Brasil, 1924. Óleo sobre tela, c.i.d., $142 \times 126,8 \mathrm{~cm}$. Coleção Museu de Arte Contemporânea da Universidade de São Paulo (SP). Reprodução fotográfica Romulo Fialdini.

Disponível em: <http://www.itaucultural.org.br $>$. Acesso em: 31 mai. 2011

resíduos nos corpos d'água e disputando a ocupação do território com suas edificações, provocaram um olhar questionador dos artistas daquele momento, prontos para registrar com a ponta do pincel os novos arranjos paisagísticos.

A tela de Tarsila é reveladora destas transformações, pois a paisagem urbana ali retratada deixa clara, e em 
vários planos, a necessidade da energia elétrica como o combustível da nova dinâmica recém instalada: os postes de iluminação apresentam o mesmo grau de importância e destaque que as torres, que os caminhos ou trens, que são o tema do quadro. Pintados em traçado largo e tinta preta, tanto os postes quanto as torres figuram na pintura como uma sugestão de contorno geral da paisagem. É como se todos os outros elementos, as residências, igreja e árvores, estampados em colorido, estivessem adornados pelos postes e torres, numa deferência à necessidade da energia elétrica como substância que modela o arranjo espacial.

A figura 4 do pintor e gravurista gaúcho Hofstetter, além oferecer a apreciação e análise de uma técnica que difere do óleo sobre tela das figuras anteriores, a técnica da linoleogravura com um traçado mais pesado favorece e acentua a dramaticidade implícita na representação dos tipos humanos em preto e branco, e ainda privilegia o cenário urbano plenamente tomado das construções e artefatos humanos.

A presença do poste de iluminação localizado exatamente ao centro da paisagem com seus fios afastando-se em leque, na perspectiva para a direta e acima, são um inequívoco atestado da importância da energia elétrica e sua presença insinuante nesta paisagem, na qual os fios de eletricidade são praticamente o único indicador de movimento na representação e ao mesmo tempo sugerem sua conexão com uma continuidade

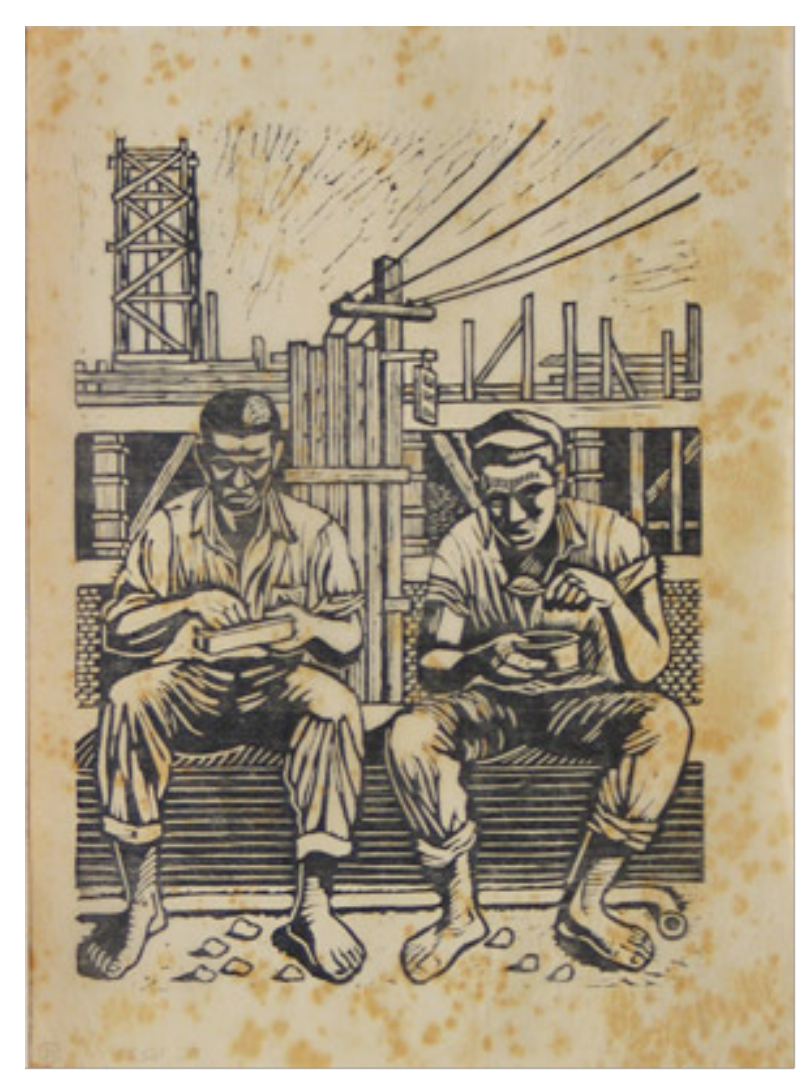

Figura 4 - HOFSTETTER, Gastão. Obra, 1952. Linoleogravura, $31 \times 22 \mathrm{~cm}$. Doação Carlos Scliar. Disponivel em: <http://www.pinacoteca.org.br>. Acesso em: 14 ago. 2011

Geograficidade | v.4, n.1, Verão 2014 ISSN 2238-0205 externa ao enquadramento. O desenho do poste em cruz, no centro da tela, de certa forma sacraliza a importância da eletricidade no ambiente urbano.

As condições nas quais os dois personagens estão se alimentando, suas vestes, pés descalços e a situação de um cenário em obras atrás deles sugere ainda outras reflexões, como as migrações internas, o subemprego e a urbanização nas grandes cidades, fora do eixo Rio-São Paulo.

A paisagem urbana, no decorrer do século $X X$, se adensou de formas verticalizadas, compôs-se de novos arranjos emaranhados pelos fios condutores dos novos fluxos de energia e comunicação e ganhou uma composição de cores pontuada pelo acinzentado do concreto predominante nas edificações.

Nas artes, a temática urbana começou a exercer certo fascínio ao olhar dos artistas, que percebendoa fragmentação do espaço urbano pontuado de novos artefatos que passam a compor essas paisagens, compuseram obras paisagísticas que destacam a relevância adquirida por certos elementos como a rede elétrica nos novos arranjos espaciais observados.

Na Figura 5, Cândido Portinari expressou com maestria a preponderância dos postes de eletricidade que, no ambiente urbano moderno, impedem que se aviste o céu ou o horizonte sem a intermediação de seus fios condutores, a partir do ponto de vista das calçadas, principalmente. É raro conseguir um enquadramento em que os postes de iluminação não estejam presentes nas paisagens urbanas, a ponto de se tornarem protagonistas em algumas composições. 


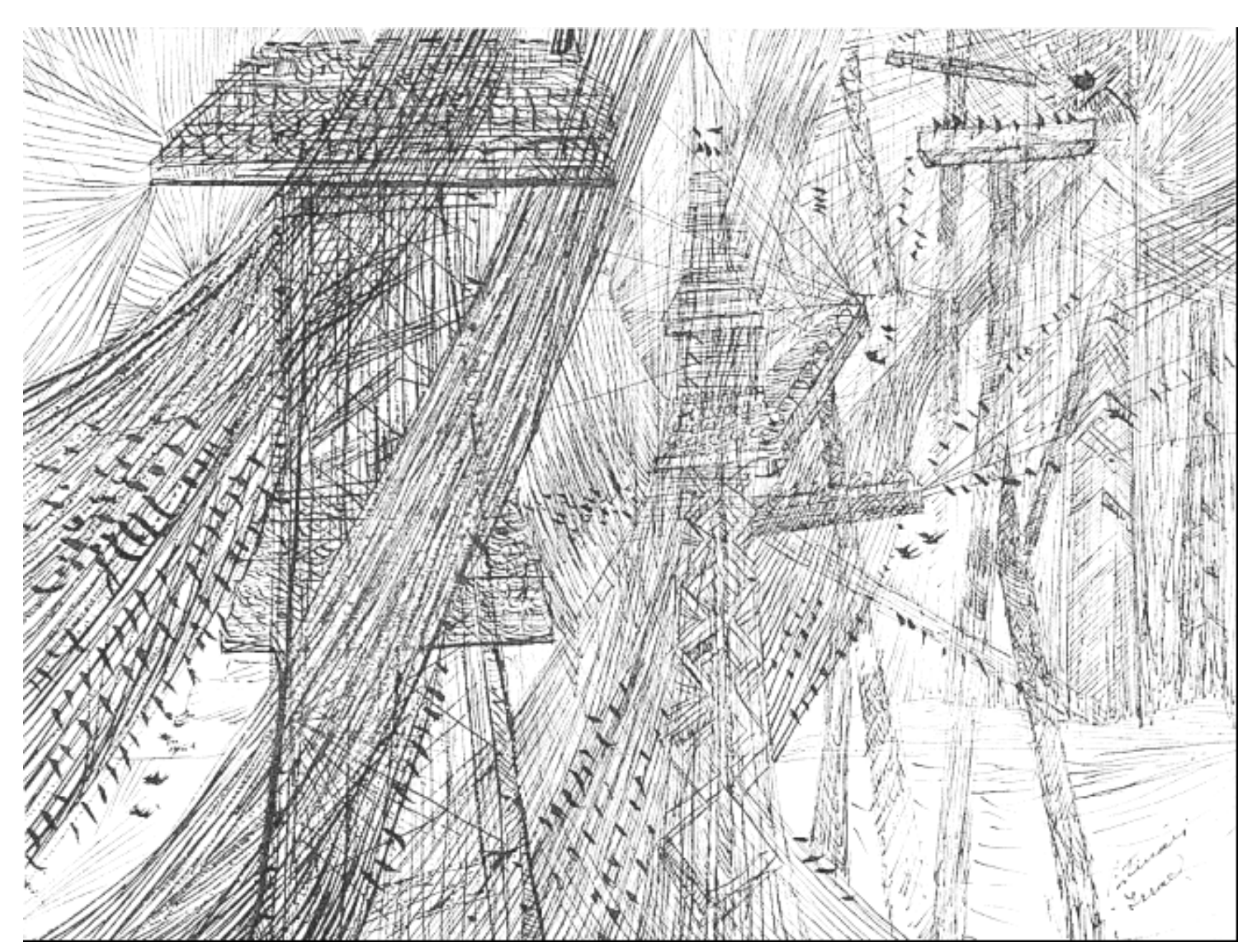

Figura 5-PORTINARI, Cândido. Rede Elétrica. [1956]. Desenho a nanquim bico-de-pena/papel, $27 \times 35 \mathrm{~cm}$. Rio de Janeiro, RJ. Coleção particular.

Disponivel em: <http://www.itaucultural.org.br>. Acesso em: 12 ago. 2011

Portinari, sempre tomado de forte preocupação social e buscando captar tipos populares e o papel do trabalhador, nesta obra da Figura 5, eximiu a paisagem da presença humana, para retratar toda a dramaticidade da interiorização da energia elétrica e a transformação das paisagens nacionais e modernas.

Neste desenho de Portinari, a Rede Elétrica é o ator principal da representação que expressa simbolicamente por meio das linhas curvas do emaranhado de fios a intensificação e ampliação dos fluxos de energia e comunicação que caracterizam as cidades globais. O olhar que observa a figura acompanha o movimento dos traços, nos levando à percepção das mesmas ondas em que a energia flui pelo espaço geográfico.

A paisagem contemporânea quase sempre aparece moldada num gráfico cartesiano formado pelos elementos de transmissão e distribuição de energia, cujas linhas verticais são os postes e as linhas horizontais são os fios de transmissão. Na Figura 6, a artista multimídia paulistana, detém-se num fragmento do caótico conjunto de artefatos urbanos e nos proporciona um close de um poste de iluminação que, soberano na representação em técnica mista sobre papel, comunica toda a força e potência que possui como instrumento de transmissão de energia destes novos arranjos paisagísticos e dramaticamente como tema das representações plásticas.

Nas zonas urbanas, em que os postes de transmissão de energia foram de tal forma absorvidos pelas paisagens, quer se queira avistar o cév ou a linha do horizonte, é raro enquadrarmos uma pequena porção da paisagem sem que a presença destes artefatos delineiem a perspectiva. Na Figura 6 ele é o protagonista, entretanto, uma intervenção urbanística adotada tanto em grandes centros urbanos quanto em cidades históricas têm sido a fiação subterrânea, que, além de oferecer uma alternativa estética à poluição visual, também representa uma redução nos riscos que a fiação aérea oferece com possibilidade de choques e blecautes.

No Brasil é possível vislumbrar paisagens urbanas isentas de postes de energia elétrica na Avenida 
Paulista, em São Paulo, e em algumas outras avenidas e cidades como Belo Horizonte, São Luís, Rio de Janeiro e Goiânia (Fonte: sites consultados). Na cidade de Goiás (conhecida também como Goiás Velho), a instalação de fiação subterrânea foi condição imposta pela UNESCO para que a cidade se tornasse Patrimônio Cultural da Humanidade em 2001.

As novas organizações espaciais têm sido, com frequência, condicionadas pela ampliação do uso e da produção de energia elétrica. As paisagens noturnas e sua correspondente iluminação artificial se distinguem nas composições paisagísticas configuradas a partir do novo modelo de paisagem.

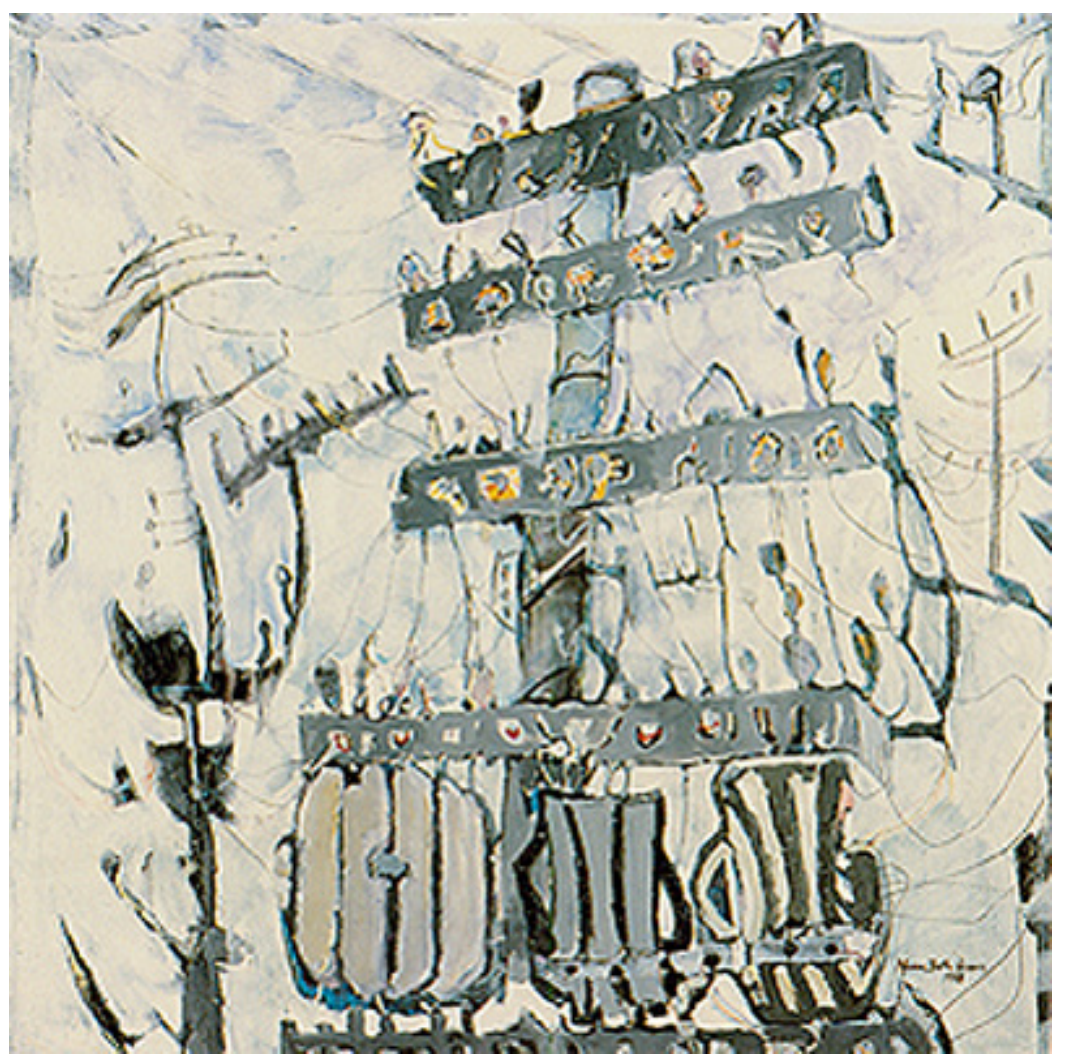

Figura 6-BARTH, Mônica. Instalações B, 1987. Técnica mista sobre papel, $100 \times 100 \mathrm{~cm}$. Reprodução Fotográfica de Antônio Sages-

Disponível em <http://www.itaucultural.org.br>. Acesso em: 03 mai. 2012

Geograficidade | v.4, n.1, Verão 2014 ISSN 2238-0205
A tela da Figura 7 de Gregório Gruber é um destes exemplos, nos quais a cidade revela uma experiência singular na pintura e na observação. Como um ator que atua num palco sob a iluminação dos spots, as edificações do centro da cidade de São Paulo, que durante o dia passam despercebidas pelo tumulto de pessoas que cruzam alucinadamente suas ruas, à noite ganham destaque, imponentes, verticais, solitárias no vazio que se instala após o por do Sol na região central da cidade.

Entretanto, no caso desta tela, a iluminação não é apenas um acessório que vivifica as edificações, ela também protagoniza a

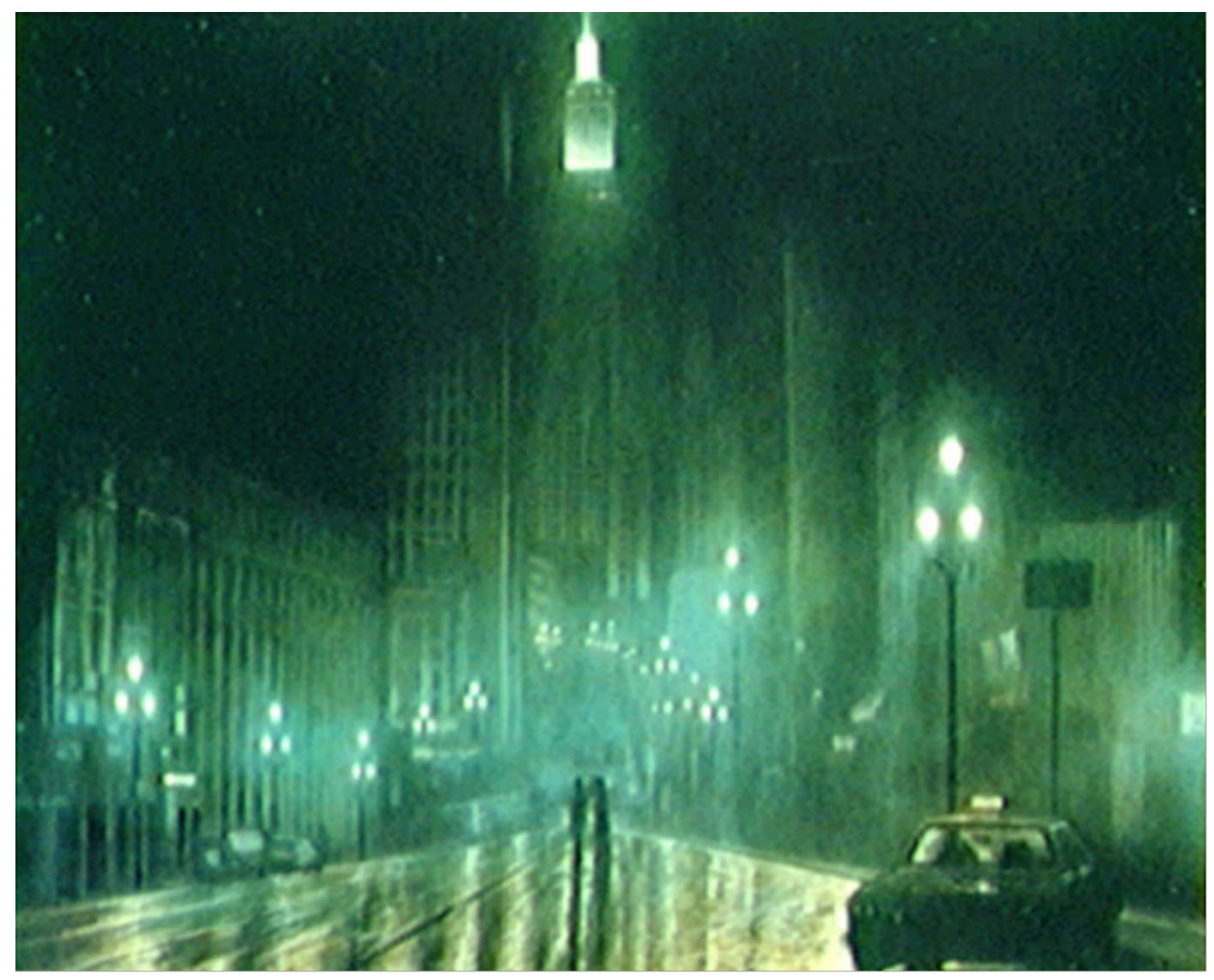

Figura 7-GRUBER, Gregório. Av. São João à Noite. Óleo sobre tela, 160 x $210 \mathrm{~cm}$. Disponível em: <http://www.itaucultural.org.br>. Acesso em: 09 jun. 2011 
composição por meio dos antigos e charmosos postes da Ligth feitos de ferro fundido (Site São Paulo Antiga). Adaptados para funcionar com a nova tecnologia de produção de energia, estes postes da década de 20 compõem a paisagem urbana da área central da cidade e neste quadro de Gregório Gruber substituem as pessoas que à noite abandonam o centro deixando-o vazio, mas que ainda resta pulsante de energia.

A organização interna da paisagem representada por Gregório Gruber atrai o olhar do observador para o arranjo e o brilho das luzes. São elas que orientam a perspectiva e condicionam a compreensão e apreciação das formas verticalizadas, enevoadas ou refletidas no brilho do piso molhado. A predominante ausência de pessoas (apenas sugerida na passagem de um táxi à esquerda), vegetação ou animais na representação, se contrapõe completamente ao conceito de paisagem do século XVIII. O que comprova a reformulação tanto da paisagem como gênero da pintura, quanto da paisagem geográfica.

Novamente a intensidade da luz das cidades pode ser apreciada na suposta visão vertical de uma paisagem representada na tela "Cidade lluminada" de Antônio Bandeira (Figura 8). Com olhar um pouco mais cuidadoso é possível decompor vários planos de iluminação nesta pintura. As diferentes cores nos pontilhados podem sugerir um plano de iluminação de rua, um conjunto de luzes que poderiam ser identificados como veículos e ainda um grupo de luzes das residências, cada uma atribuída a uma cor: amarelo, vermelho e branco. Estes pontilhados quando visíveis a partir do plano vertical sugerem um mosaico de luzes e cores dispostas sobre o preto que sugere um arruamento quadriculado nas bordas e uma massa homogênea na área central da tela.

Afastando-se um pouco das áreas urbanas, a biomassa e a associação entre produção agrícola e energética, converteram-se na paisagem modificada pelos complexos agroindustriais. A biomassa, alternativa

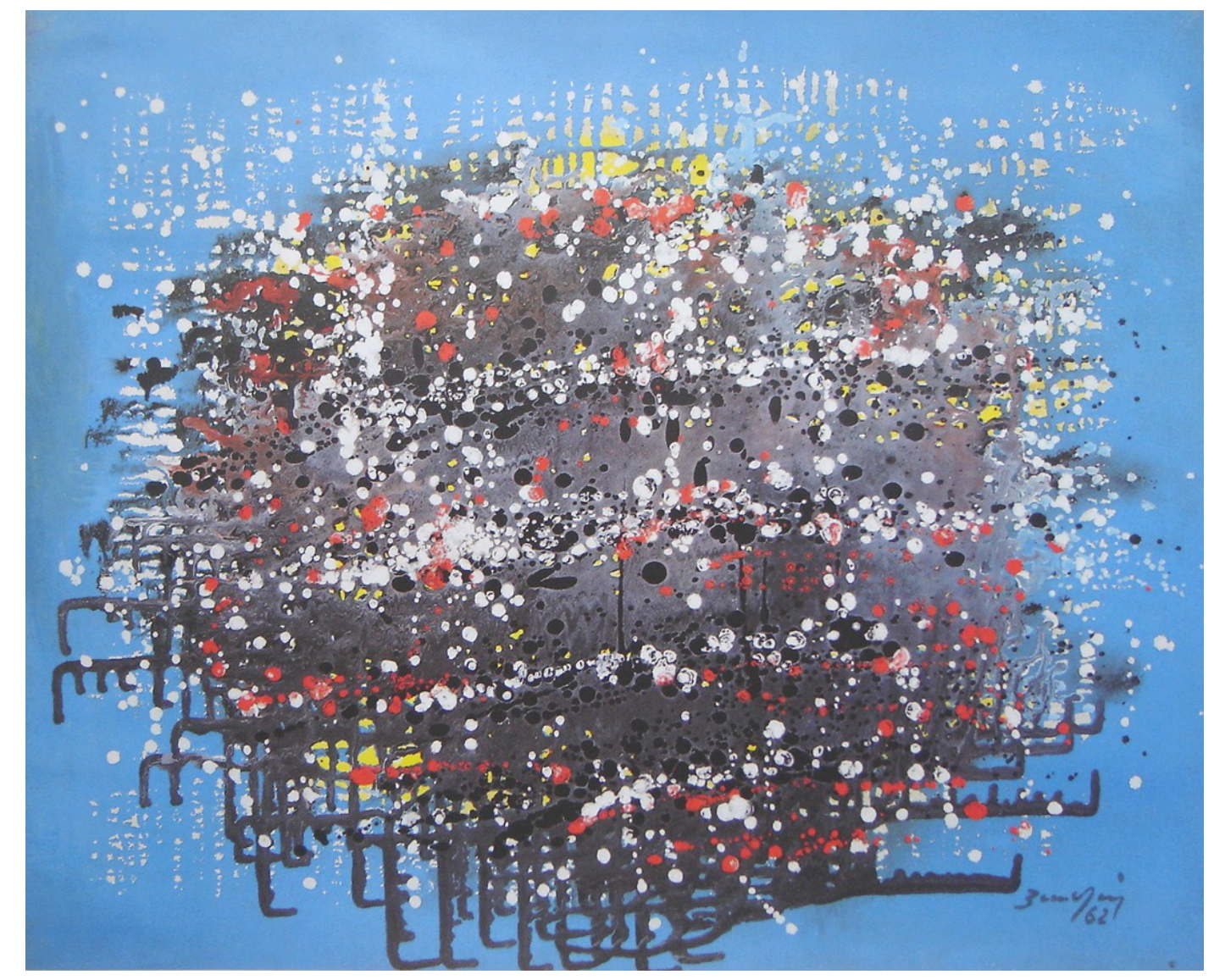

Figura 8 - BANDEIRA, Antônio: Cidade lluminada, 1962. Óleo sobre tela - 50 ×61,5cm. Coleção Roberto Marinho, Rio de Janeiro.

Fonte: NOVIS, 1966, p. 217

de fonte de energia considerada renovável, é definida como qualquer matéria orgânica que possa ser transformada em energia mecânica, térmica ou elétrica. É classificada de acordo com a sua origem, podendo ser florestal (madeira, principalmente), agrícola (soja, arroz e cana-de-açúcar, entre outras) e rejeitos urbanos e industriais (sólidos ou líquidos, como o lixo).

Os principais benefícios na geração de energia a partir da biomassa é a geração de empregos diretos e indiretos, a inclusão social, a geração de novas atividades econômicas, o fortalecimento da indústria local, a promoção do desenvolvimento regional e a redução do êxodo rural. 
Entretanto, como aspectos negativos e impactantes destacam-se a possibilidade da formação de monoculturas em grande extensão de terras e a competição com a produção de alimentos. Porém, estas variáveis têm sido contornadas por técnicas e processos que aumentam a produtividade da biomassa reduzindo a necessidade de expansão de áreas plantadas.

A logística desta cadeia produtiva permite máximo aproveitamento da produção além de tonar o complexo agroindustrial praticamente sustentável em termos de geração e consumo de energia. A Figura 9 é um exemplo de transformação paisagística, no qual pode-se constatar

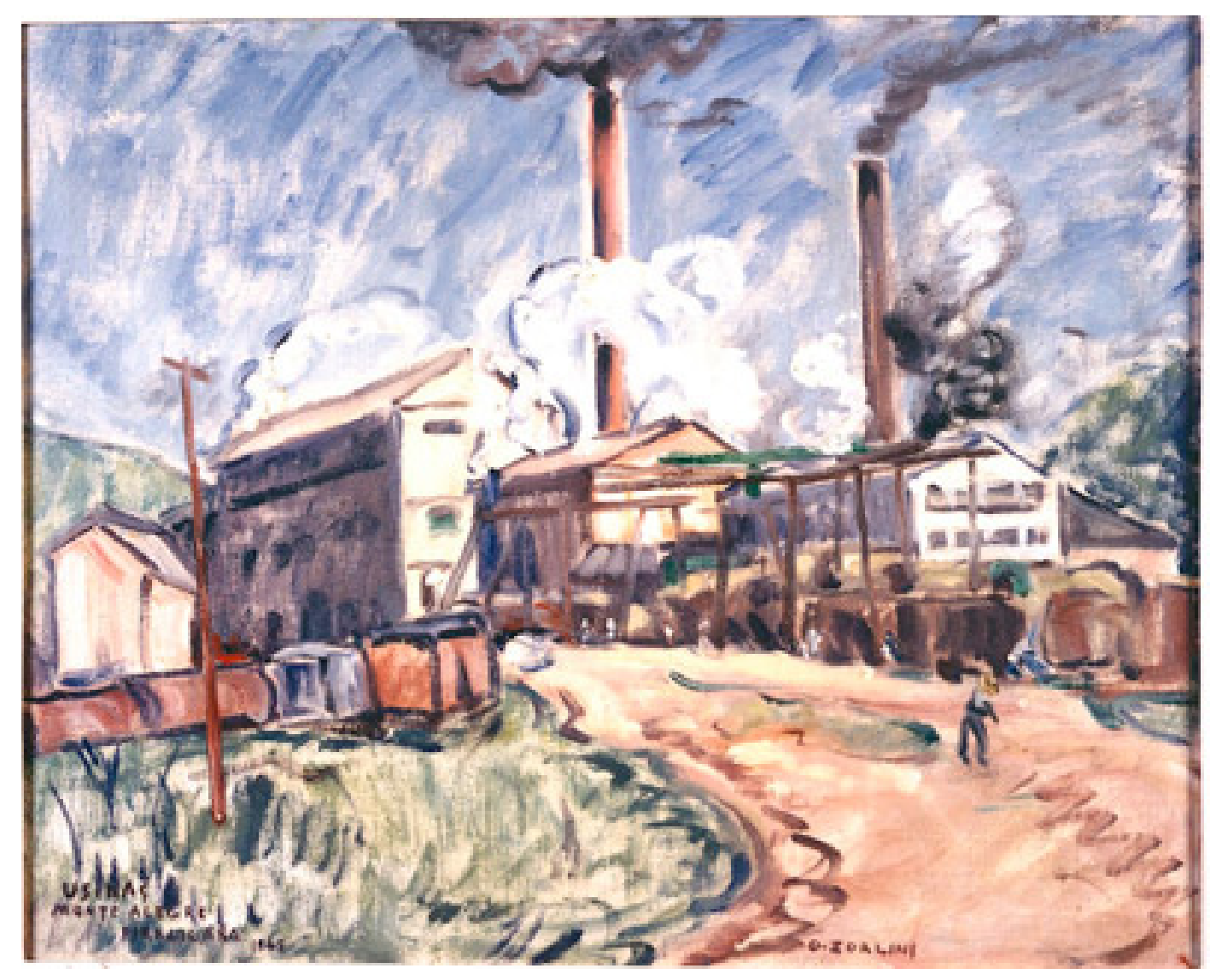

Figura 9-ZORLINI, Ottone. Usina Monte Alegre, 1965. Óleo sobre tela, 38,5 × 48cm. Acervo da Pinacoteca (SP) - Doação, Giancarlo Zorlini.

Disponível em: <http://www.pinacoteca.org.br>. Acesso em: 15 ago. 2011

Geograficidade | v.4, n.1, Verão 2014

ISSN 2238-0205 que a exuberância da verticalidade de uma chaminé soltando fumaça não é mais exclusividade dos centros urbanos.

A tendência de transformação dos espaços rurais em grandes complexos agroindustriais relaciona-se à biomassa como fonte de energia, pois a busca pela maior eficiência e produtividade tem levado à utilização do bagaço da cana e outros rejeitos orgânicos na produção de energia a partir da queima destes em pequenas centrais geradoras de energia.

A demanda pela produção de combustíveis carburantes propagou a construção de usinas por vastas áreas rurais no interior do país e foi responsável também pelo processo de concentração fundiária e substituição de culturas para a produção de matéria-prima para as usinas de álcool. A Usina de Monte Alegre da figura 9, originalmente uma fazenda de café e açúcar, é um dos vários exemplos de adaptação do processo produtivo e cadeia produtiva que se adaptaram à crescente demanda por fontes energéticas do mundo moderno.

\section{PAISAGENS QUE REVELAM POTENCIAL ENERGÉTICO}

Essa crescente demanda por fontes de energia somada às sucessivas crises de petróleo no século XX estimularam pesquisas e ampliação de fontes alternativas de energia. Neste quesito, o Brasil tem se destacado por apresentar um potencial eólico com ventos duas vezes superiores a média mundial e apenas $5 \%$ de oscilação da velocidade, com potencial aumentado na época da estiagem em algumas regiões (BRASIL, 2008). Atualmente é uma das fontes de energia cuja produção mais cresce no país.

A energia eólica é obtida da energia cinética das pás de um catavento que é movido pela migração das massas de ar. Apesar do baixo potencial instalado no país, este tipo de energia é um dos que mais 
tem crescido nos últimos anos e o Brasil figura no cenário mundial como um país com elevado potencial, principalmente no litoral Nordestino, no Vale do Jequitinhonha na região Sudeste e no Rio Grande do Sul. Parte deste potencial está estampado nas Figuras 10 e 11 . Se instalado todo o potencial, o impacto certamente seria visível, substituindo o movimento do ar sugerido nas pinceladas pelas figuras de grandes cata-ventos.

Nas paisagens das Figuras 10 e 11 pode-se observar a representação estilística do potencial eólico que o Brasil possui. O gaúcho Mayer expressa por meio de formas e cores a contundência do típico vento norte que assinala o cotidiano do sul do país principalmente nas situações de préfrontais. Enquanto Anita Malfatti (Figura 11), deixa evidente na expressão de suas pinceladas o movimento intenso que a ventania provoca na paisagem, revelando o potencial de algumas regiões no Brasil.

Apesar de ser um país tropical o uso da energia solar no Brasil também é pouco expressivo, representando um total de pouco mais $50 \%$ da capacidade instalada da usina hidrelétrica de Itaipu (BRASIL, 2008). Provavelmente por isso nenhum registro de seus painéis fotovoltaicos

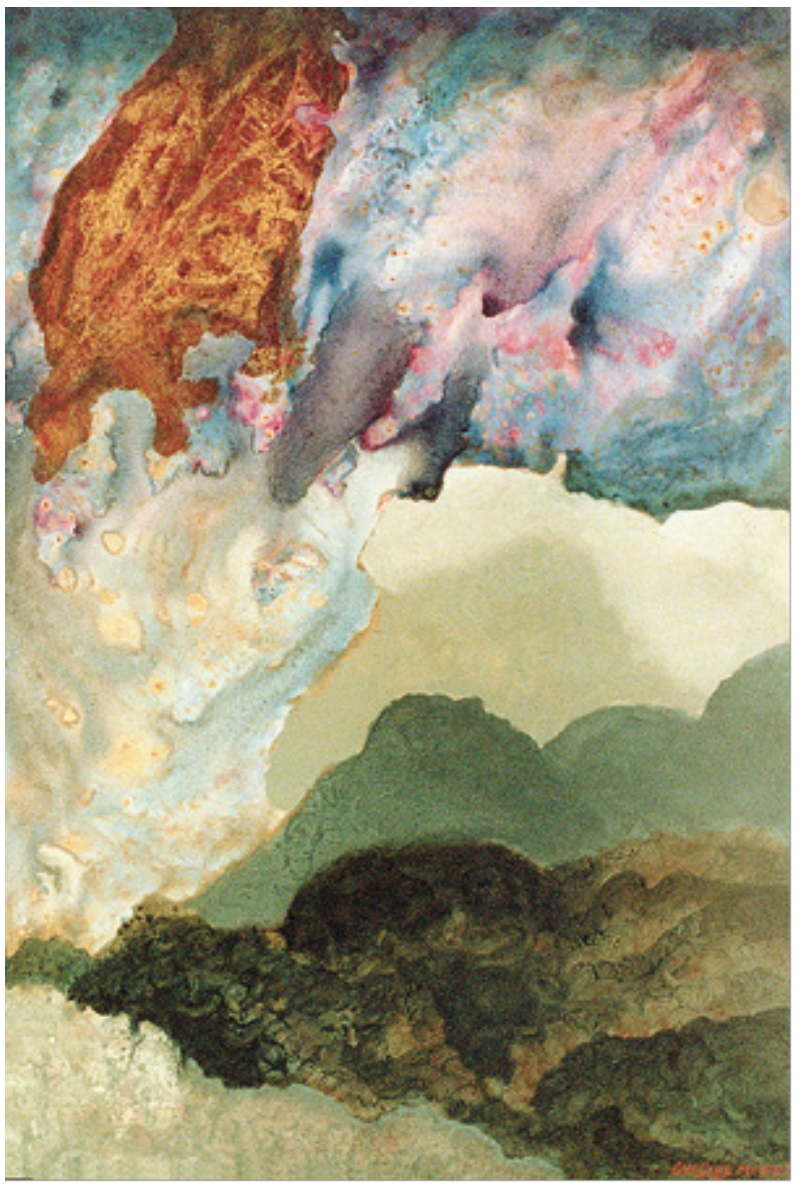

Figura 10 - MAYER, Charles. Vento Norte, 1985. Acrílica sobre Duratex, c.i.d., $121,5 \times 84,5 \mathrm{~cm}$. Acervo Banco Itaú S.A. (São Paulo, SP).

Disponivel em: <http://www.itaucultural.org.br >. Acesso em: 7 mai. 2012

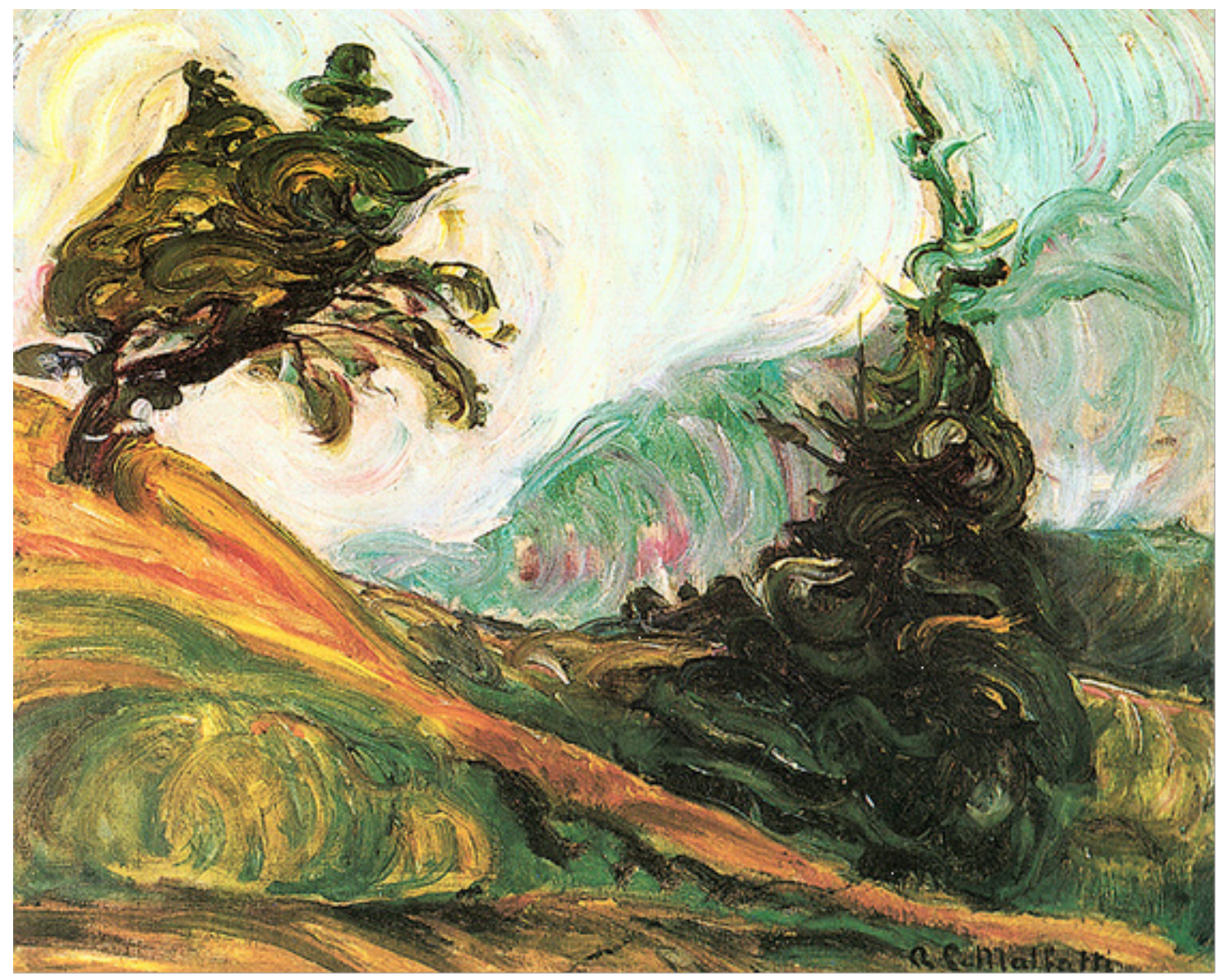

Figura 11 - MALFATTI, Anita. A Ventania, 1915-1917. Óleo sobre tela, c.i.d., 51 x $61 \mathrm{~cm}$. Acervo Artístico-Cultural do Palácio do Governo do Estado de São Paulo, Palácio dos Bandeirantes. Reprodução fotográfica Romulo Fialdini.

Disponível em: <http://www.itaucultural.org.br>. Acesso em: 7 mai. 2012 
foi encontrado impactando as imagens estudadas, mas certamente a intensidade da luz dos trópicos está implícita na maioria das paisagens pintadas.

No que se refere às transformações paisagísticas e da paisagem como gênero da pintura, as figuras 8, 10 e 11 demonstram claramente a transição do gênero, cuja abstração da representação permite flexibilidade nas regras de projeção, acolhendo vários pontos de vistas e planos, mesclando visão horizontal, vertical e oblíqua numa única tela. A subjetividade aflora por meio de uma composição que sugere a representação de percepções que vão além das visuais, com a valorização do movimento ou das nuances de temperatura, insinuadas no uso predominante das cores quentes ou frias.

As pinturas de paisagens passaram a acolher nas suas composições tantos elementos quanto as paisagens geográficas passaram a estampar em seus conjuntos. No século XX a maioria da população mundial passou a viver em áreas urbanas, portanto em conjuntos paisagísticos cuja fórmula idílica do século XVIII foi dando lugar aos artefatos construídos pelo homem.

\section{DISCUSSÕES E CONCLUSÕES FINAIS}

Considerando a pesquisa e o projeto que deram origem a este artigo, foram selecionadas cerca de 50 imagens de pinturas de paisagens que permitem identificar algum tipo de impacto referente à ampliação do uso de energia elétrica no Brasil ou, dentro da classificação apresentada, que são registros anteriores ao impacto da instalação de produção e exploração de fontes de energia ou paisagens que apresentam potencial para exploração de alguma fonte de energia.

Dentre as imagens, há registros históricos de paisagens atualmente impactadas pela instalação de fontes de energia ou adoção de novas atividades econômicas voltadas à produção de energia. Há paisagens impactadas devido à ampliação do uso das fontes e redes de distribuição de energia, em geral sítios urbanos pontuados pela presença de postes sobre os quais estão apoiados cabos de eletricidade que manifestam, quase sempre, a função de referencial para a construção da perspectiva nas telas. Há também artefatos relacionados à obtenção de energia elétrica que transformaram o modo de vida urbano e rural e a iconografia relativa a estas paisagens geográficas. São pinturas cujos elementos naturais passaram a figurar como pano de fundo na nova dinâmica urbana.

Os resultados obtidos a partir da análise do registro dessas transformações nas pinturas de paisagens permitiram traçar um elenco de impactos advindos da geração, transmissão e distribuição de energia e um quadro das transformações da paisagem geográfica no mundo contemporâneo. Tais pinturas demonstram que a iconografia pode se constituir em instrumento facilitador da percepção da paisagem, fonte de informações históricas e objeto de apreciação estética por si só, além de fomentar a aproximação das obras de arte e a sala de aula (quando pensado no projeto FIPE que deu origem a esta análise) para além de uma minoria que consome arte no país.

\section{REFERÊNCIAS}

BARBOSA, Ana Amália Tavares Bastos. Releitura, citação, apropriação ou o quê? In: BARBOSA, Ana Mae (Org.). Arte/Educação contemporânea: consonâncias internacionais. São Paulo: Cortez, 2005, 432. p. 143-149.

BERQUE, Augustin. Paysage et Modernité. Notes de lecture em forme d'hypothèse. L'Espace Géographique, Paris, n. 2, p. 137-139. 
BRASIL. Agência Nacional de Energia Elétrica (ANEEL). Atlas de energia elétrica do Brasil. Parte II (Fontes Renováveis), no 5 (Outras

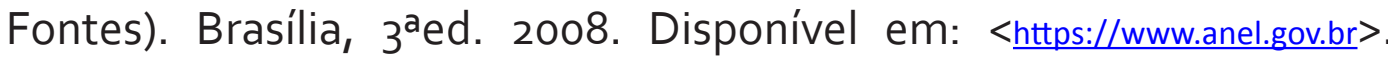
Acesso em: 2011.

CAUQUELIN, Anne. A invenção da Paisagem. Tradução de Marcos Marcionilo. São Paulo: Martins: 2007.

CORREAA, Roberto Lobato; ROSENDAHL, Zeny. (Orgs.). Introdução à Geografia Cultural. Rio de Janeiro: Bertrand do Brasil, 2003.

CORRÊA, Roberto Lobato; ROSENDAHL, Zeny. Paisagem, tempo e cultura. 2ed. Rio de Janeiro: EdUERJ, 2004.

FUNDAÇÃO IPARDES. Impacto Ambiental de Itaipu. Curitiba, 1981, 3v.
MONTEIRO, Carlos Augusto de Figueiredo. Geografia Sempre: O Homem e seus Mundos. Campinas: Edições Territorial, 2008.

MYANAKI, Jacqueline. Geografia e Arte no Ensino Fundamental: reflexões teóricas e procedimentos metodológicos para uma leitura da paisagem geográfica e da pintura abstrata. 2008. 236f. Tese (Doutorado) - Departamento de Geografia da Faculdade de Filosofia, Letras e Ciências Humanas da Universidade de São Paulo. São Paulo, 2008.

NOVIS, Vera. Antônio Bandeira, um raro. Rio de Janeiro: Salamandra, 1996.

ROGER, Alain. Court traité du paysage. Paris: Éditions Gallimard, 1997. 